\section{Historien om en sidegevinst}

Af forskningsstipendiat Ole Kongsted

$\mathrm{M}$ ange kender vel dette i forbindelse med en videnskabelig undersøgelse at lede efter ét og så mere eller mindre tilfældigt at "falde“ over noget andet. I forbindelse med mit arbejde omkring hofmusikkultur i Balticum med særligt henblik på forholdene i Danmark i 1500-tallet identificerede jeg for nogle år siden en i det store og hele komplet overleveret fyrstelig musiksamling fra Renaissancen i universitetsbiblioteket i Rostock. Samlingen viste sig at stamme fra det hertugelige mecklenburgske hof ca. 1550 - ca. 1576. Jeg har gjort rede herfor andetsteds, og denne redegørelse skal ikke omtales nærmere her.

En efterfølgende undersøgelse af samlingens manuskripter afslørede, at de fleste var skrevet af hertug Johann Albrecht I's kantor ved fyrsteskolen i Schwerin, Nicolaus Sartorius (+ 1566). Sidstnævnte havde i 1550 'erne i Schwerin blandt meget andet afskrevet Christian IIIs hofkapelmester Josquin Bastons Missa super Bewahr mich, Herr - en messe, der efterfølgende skulle vise sig at være et af musikhistoriens tidligste eksempler på en polyfon bearbejdelse af en tysk protestantisk „Kirchenlied“. Baston var i 1557 på vej fra sin stilling som kontratenor ved kurfyrst Augusts hof i Dresden til stillingen som kongelig kapelmester i København. Man kan forestille sig, at vejen til København er gået forbi det musikelskende schwerinske hof, og at han siden er rejst med båd fra
Rostock til Gedser; dette var i hvert fald - dengang som senere - en af de vigtigste måder at rejse fra Tyskland til Danmark på, hvis man ikke ville tage den lange vej over land, hvor man alligevel skulle to gange over vand.

Et af manuskripterne i universitetsbiblioteket i Rostock indeholder som sagt Bastons messe, som ud over sin musikhistorisk interessante placering, også er det tidligste polyfone ordinarium missae af en komponist med tilknytning til Danmark. Et andet af schwerinermanuskripterne: ROu, Ms. Mus. Saec. XVI nr. 52, indeholder en lang række, hvad man kunne kalde „Renaissanceschlagere", - kirkelige værker, der findes igen og igen i 1500-tals afskrifter i forskningsbiblioteker over hele Europa: Jacobus Clemens non Papa: Pater peccavi, samme komponist: Gott ist mein Licht, Jean Maillard: In me transierunt, Stephan Zirler: Bewahr mich, Herr (som Bastons messe er "modelleret" over) og flere andre. I alt er her: 4 værker af Thomas Crecquillon, 5 af Clemens non Papa, 8 af Josquin Baston, 4 af Jakob Arcadelt, 1 af Philippe Verdelot, et par værker af, hvad tyskerne med en besynderlig terminus kalder "Kleinmeister" samt endelig et par anonymer.

Uheldigvis er samlingen inkomplet, idet kun 3 af 6 stemmebøger er overleveret: Discant, Altus og Tenor; dette er desværre invaliderende, al den stund der blandt samlingens lidt mere end 30 numre befinder sig mindst 8 unica! I forbindelse med de enklere 4stemmige værker kan man uden for mange panderynker rekonstruere basstemmmen og være meget sikker på at komme til et resultat, der ikke ligger for langt fra det, der må have være noteret i 


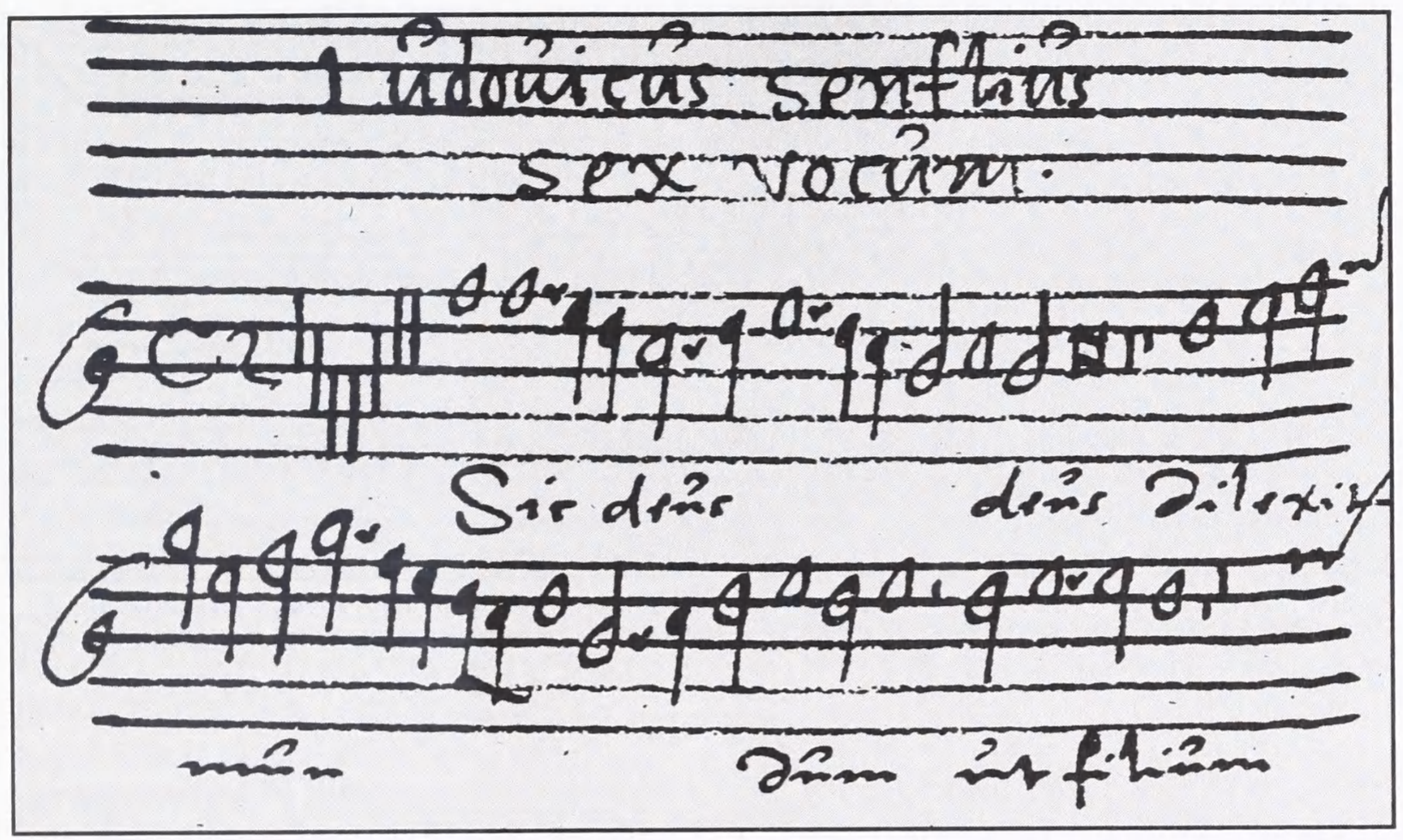

UB Rostock, Ms. Mus. Saec. XVI, 52: „Ludouicus senflius/sex vocum“. Manuskriptet - af hvilket her ses begyndelsen af Discant-stemmen-stammer fra Schwerin fra begyndelsen af 1560 'erne, og skriver er kantor Nicolaus Sartorius (+ i Schwerin 1566).

den manglende bas-stemmebog. I andre tilfælde vil en rekonstruktion i højere grad være exercits for teorilærere, hvilket selvsagt kan være interessant som øvelse, men mindre interessant $i$ en historisk sammenhæng.

Ud over de nævnte værker findes i dette manuskript et enkelt værk med komponistsignaturen "Ludouicus Senflius"; det drejer sig om en 6-stemmig motet i den hypomixolydiske toneart over teksten til Johannes-evangeliet 3, 16: Sic Deus dilexit mundum. Et blik på de 3 stemmer i UB Rostock afslørede, at var er tale om en stort anlagt motet over knap 100 brevismensurer ["takter"] med et smukt afbalanceret tema, der imite-rende blev sat ind successivt, således at alle stemmer formentlig først ville være i gang efter 15-16 brevismensurer. Ydermere kunne motetten ses at være bygget op over den grego- rianske antifon fra Feria Secunda infra Octavam Pentecostes. Der var selvfølgelig den mulighed, at Sarto-rius' tilskrivning til Ludwig Senfl (1486-1542/43) -en af Luthers yndlingskomponister - kunne være forkert, men jeg husker tydeligt, at torso'en gjorde et klart indtryk af at være konciperet af en mester af faget. Og jeg husker ærgrelsen over at sidde med resterne af noget, der måtte have været et substantielt værk. For ikke-musikhistorikere blot den oplysning, at Senfl var Heinrich Isaacs efterfølger som komponist ved kejserhoffet og senere Orlando di Lassos forgænger som hofkapelmester ved det hertugelige bayerske hof i München; vi taler således om en af 1500-tallets betydeligste - og også i samtiden berømte - komponister.

Diverse opslag de relevante steder viste, at en sådan motet ikke fandtes i den "Gesamtausgabe“ over 


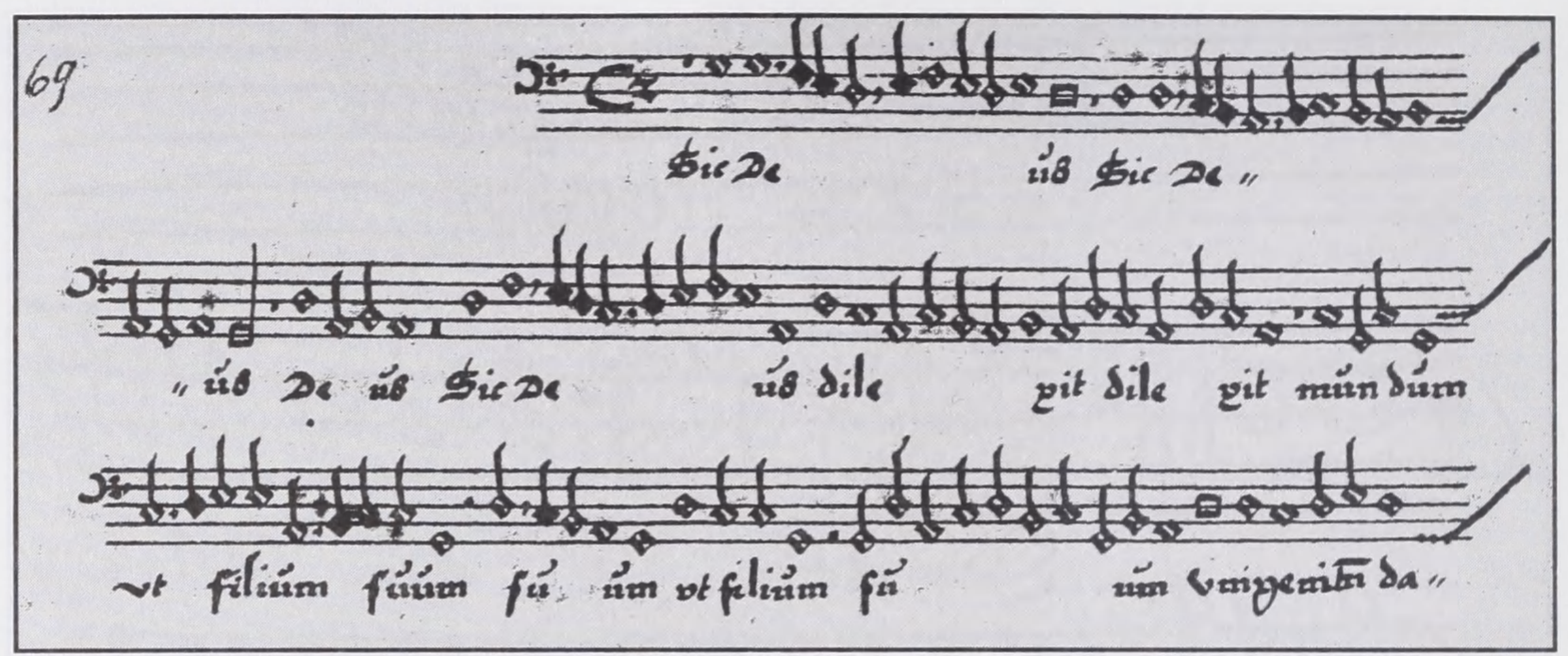

Den anonyme Sic Deus dilexit mundum i Ratsschulbibliothek Zwickau; begyndelsen af Bassus.

Senfls produktion, der begyndte at udkomme i 1937 og som stoppede med bind XI i 1974. Opslag i de store musikleksika førte ikke til noget; den relevante speciallitteratur gav én anvendelig oplysning: i en katalog over det kurpfalziske musikbibliotek i Heidelberg fra 1544 fandtes en notits om, at man på dette tidspunkt havde haft en 6-stemmig Sic Deus dilexit mundum af Senfl i nodearkivet. Værket eksisterede altså dengang i Heidelberg som materiale for pfalzgrevens hofkapel - et af de betydeligste i samtidens Europa - og var forsvundet $\mathrm{i}$ eftertiden.

UB Rostock var ét af de første steder, jeg besøgte. I jagten på manuskripter af komponister med tilknytning til dansk musikhistorie bragte mit projekt mig 1994-1999 til omkring 60 forskningsbiblioteker i Tyskland, Holland, Belgien, Frankrig, Italien, Schweiz, Østrig, Polen, Estland, Letland og Sverige. Hvor jeg kom frem, så jeg altid efter, om der skulle være en Sic Deus dilexit mundum. Det var der flere steder, men altid motetter af andre komponi- ster; stødte jeg endelig på en 6-stemmig anonym sats til denne smukke tekst, viste det sig kedeligt nok altid at være Franciscus de Rivulos motet.

I ndtil i forgårs! - I forbindelse med et gennemsyn af nogle 1500 -tals manuskripter i Ratsschulbibliothek

Zwickau gennemgik jeg Mss. 69.1.57.62, en i Renaissance-musikforskningen berømt samling stemmebøger, nemlig det såkaldte Schalreuter-manuskript, opkaldt efter dets skriver og kompilator. Det drejer sig om 6 smukt restaurerede stemmebøger, som har deres egen særprægede historie; denne fremgår af en længere latinsk klamamse, som er noteret på forpermen $\mathrm{i}$ tre af bøgerne. Kort fortalt går historien ud på, at bøgerne blev skrevet - en smuk, letlæselig mensuralnotation - af en musicus i Zwickau, Jodocus Schalreuter i 1540'rne; samme Schalreuter var et offer for religionskrigene, idet han faldt i forbindelse med forsvaret af Magdeburg i 1550. En borger i Zwickau, Georg Neumeister, købte bøgerne af arvingerne og forærede dem 
til Ratsschulbibliothek Zwickau i 1553. Her ligger de endnu knap 450 år senere $i$ et fint gammelt humanistbibliotek i en af de vigtige Luther-bastioner med solide kantor-traditioner, der rækker helt tilbage til Reformationstiden. Forskningen har ikke været enig i forbindelse med dateringen af bøgerne og har med henblik herpå overset et værk, der forsyner os med en dato post quem: Anonymus: Exultent, saliant, plaudant/Connubio stabili Ferdinandi filia regis juncta tua Maria est Dux Gulielme thoro, 5 vocum. Det kan kun dreje sig om kong Ferdinand (1503-1564), senere kejser Ferdinand I, hvis datter Maria blev gift med hertug Wilhelm „der Reiche“ af JülichBerg d. 17. juli 1546 i domkirken i Regensburg. En dato ante quem er selvsagt givet med oplysningen om Schalreuters død i 1550.

I disse 6 bøger stod som nr. 7 blandt de 6-stemmige værker en anonym Sic Deus dilexit mundum. Det var 5 år siden, jeg havde ikke de tre stemmer fra Rostock ved hånden, men jeg var meget sikker på, at det var "den rigtige“. Et hurtigt indkøb af nodepapir inden lukketid fredag i den eneste butik i den gamle kulturby, der forhandlede node- papir - kun én slags, der til gengæld var ubrugeligt til formålet - en hurtig transskription af de fotokopier, jeg havde snakket bibliotekspersonalet til at give mig med på rejsen, gjorde mig 99,9\% sikker. Var det ikke Senfl, var det under alle omstændigheder en herre med et mesterligt håndelag. Endelig, for at være helt sikker: en telefonopringning til Elly Bruunshuus Petersen fra Carl NielsenUdgaven, der blev forstyrret d.d. i Jesu Hjerte Kirke midt under prøven på musikken til „Laetare“, en bøn om, at hun efter kirketid ville tage hen på mit kontor i „Børnehaven“ - som i skrivende stund efter sigende står endnu - for derefter at ringe mig op og synge begyndelsen af de tre overleverede stemmer fra Rostock i telefonen - dette med henblik på en så hurtig afklaring som muligt. Det var heldigvis den rigtige!

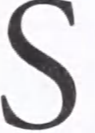

idegevinsten vil efter et nøjere studium af dette omfangsrige og særdeles interessante manuskript efter min fornemmelse vise sig at være endnu større; herom nærmere en anden god gang.

Hotel Stadt Rendsburg, Dresden Dominica Laetare, 1999 